\title{
Erratum to: Choosing an Optimal Groundwater Lowering Technique for Open Pit Mines
}

\author{
Mojtaba Golestanifar - Kaveh Ahangari
}

Published online: 5 March 2013

(c) Springer-Verlag Berlin Heidelberg 2013

Erratum to: Mine Water Environ (2012) 31:192-198

DOI 10.1007/s10230-012-0196-2

The authors would like to correct errors in the authors' affiliation in the original publication.

The authors' affiliation should be corrected as follows:

Mojtaba Golestanifar · Kaveh Ahangari

Department of Mining Engineering,

Science and Research Branch,

Islamic Azad University,

Tehran, Iran

The online version of the original article can be found under doi:10.1007/s10230-012-0196-2.

M. Golestanifar $(\bowtie) \cdot$ K. Ahangari

Department of Mining Engineering, Science and Research

Branch, Islamic Azad University, Tehran, Iran

e-mail: m.golestanifar@srbiau.ac.ir 